\title{
The Use of Natural Plant Species of Kastamonu University Campus in Landscape
}

\author{
*Sevgi ÖZTÜRK ${ }^{1}$ Bilgehan BILGILI ${ }^{2}$ \\ ${ }^{1}$ Kastamonu University, Faculty of Engineering and Architecture, Landscape Architecture \\ Department, Kuzeykent, Kastamonu-Turkey \\ ${ }^{2}$ Kastamonu University, Faculty of Forestry, Forestry Engineering Department, Kuzeykent, \\ Kastamonu-Turkey \\ *Sorumlu yazar: sozturk@ kastamonu.edu.tr
}

Geliş Tarihi: 13.02.2015

\begin{abstract}
Cities have undergone many changes and transformations in functional and physical terms since the beginning of urban life. In this process, urbanization activities experienced at a global level have caused numerous environmental, social, cultural, and economic problems. As a result, cities in Turkey became places where ecological imbalances and environmental problems are encountered frequently.

In this study, the Kastamonu University campus area of which is still under planning and construction phase was selected as the sample area for the purpose of decreasing the effects of these problems and realizing natural landscape values within the city. There was an attempt to detect herbaceous species among the natural landscape values in the area. It was further suggested that the species that were detected with both informing and aesthetic features should be assessed, providing sustainability of the species of Hyacinthella micrantha (Boiss.) Chouard, which is endemic, Euphorbia cardiophylla Boiss.\&Heldr., and Salvia hypargeia Fisch.\&C.A.Mey by protecting them using in-situ and ex-situ methods.
\end{abstract}

Keywords: Natural Landscape, Kastamonu University Campus, Sustainability.

\section{Kastamonu Üniversitesi Kampusu Doğal Bitki Türlerinin Peyzajda Kullanımı}

Özet

Kentsel yaşamın var oluşundan bu yana kentler fonksiyonel ve fiziksel açıdan birçok değişim ve dönüşüme uğramıştır. Bu süreçte küresel düzeyde yaşanan kentleşme faaliyetleri, bir dizi çevresel, sosyal, kültürel ve ekonomik sorunlara neden olmuştur. Bu anlamda, Türkiye'de kentler, ekolojik dengesizliklerin ve çevre sorunlarının yoğun olarak yaşandığı mekanlar haline gelmiştir.

Çalışmada, bu sorunların etkilerinin azaltılması, doğal peyzaj değerlerinin kent içinde de yaşam bulması amacıyla henüz yapılaşması tamamlanmamış olan Kastamonu Üniversitesi kampüs alanı örneklem alan olarak seçilmiştir. Alanda, doğal peyzaj değerlerinden otsu türler tespit edilmeye çalışılmıştır. Tespit edilen birçok türün peyzaj düzenleme çalışmalarında hem bilgilendirme hem de estetik özellikleri ile değerlendirilmesi, özellikle endemik olan Hyacinthella micrantha (Boiss.) Chouard, Euphorbia cardiophylla Boiss.\&Heldr. ve Salvia hypargeia Fisch.\&C.A.Mey türlerin in-sitü ve ex-sitü yöntemleri ile korunarak sürdürülebilirliğinin sağlanması çalışmada ayrıca önerilmiştir.

Anahtar kelimeler: Doğal Peyzaj, Kastamonu Üniversitesi Kampusu, Sürdürülebilirlik

\section{Introduction}

Cities' development dynamics, which are high in the fast-developing world, are within a continuous change/transformation process under political, social, economic, and cultural influences. In this process, the socioeconomic and physical structure of cities may not develop positively all the time. A different period began for urban areas, particularly with the effect of westernization, which started in line with industrialization, and intense population increases that were experienced along with rural depopulation, the technology, life conditions, economic conditions, and various housing policies (Özinan, 1997). In this period, numerous environmental (global climate change etc.) (Shayaa Al-Shayaa, 2012; Aba Al-Khail et al., 2005), social (humans being alienated to the natural environment, externalization etc.), cultural (degeneration of traditional culture and urban identity etc.), and economic (use of agricultural fields for other activities, forest areas being zoned for construction etc.) problems were encountered. Again, in this period, the user made interventions that usually disrupt the structures within the texture and the environment, and this led to a 
decrease in green areas horizontally and vertically. At this stage, urban landscape planning studies aim to minimize the conflict between the different uses of urban areas. This reestablishes the relationship between human beings and nature. Furthermore, it also promotes the ability to respond to the recreational needs of living things and ecological elements become effective on city forms, protecting the natural structure and managing the outdoor green area system, which forms a sustainable urban environment as a significant implementation tool (Breheny, 1992; Haughton, 1997; Frey, 1999; Andersson, 2006; Yılmaz, 1997; Çetinkaya, 2013; Cinar et al., 2013). This allows urban landscape planning to increase the value of properties in the surrounding area and contributes to the economy (McPherson, 1992; Tyruainen, 1997.) It also provides landscape repair for problematic issues including erosion, prevention of avalanchelandslide (Baizakov and Tilenov, 2013), and the improvement of waste storage areas (Ürgenç, 1990; Braun and Fluckiger, 1998). It also creates recreation means, directs development of cities, and contributes to city aesthetics and image (Arslan et al., 1996; Leszczynski, 1999; Aslanboğa, 2002; Moore, 2002; Altay, 2012).

Urban landscape planning is a socioecological system where natural and cultural processes are shaped together (Berkes et al., 2003; Olsson et al., 2004). City ecosystems are not limited to a specific scale. The city may be an ecosystem or a basin, a district or a parcel may be an ecosystem by itself. In other words, any spatial area containing biotic and physical elements has the features of an ecosystem. On that point, university campus areas are ecosystems within themselves (Söğüt et al., 2013). Kastamonu University's Kuzeykent campus area which was selected as a sample area is positioned in a section where the relationship between urban and rural areas is intense. For this reason, it contains various affluences with respect to flora and fauna. With both structural and planting projects having been completed, the purpose of the study is to detect herbaceous species in the campus area so that these species can be used in landscape arrangement studies. It is considered that the study shall provide a significant database for protecting biodiversity and transferring it to the future generations.

\section{Material and Method}

The study was carried out on the Kastamonu University campus from May to October 2013, when the vegetation period was most effective. The city of Kastamonu is located in the Europe-Siberia (Auxin) belt with respect to plant geography (Akman, 1990). The city center is under the influence of a continental climate despite being located in a geographical position transiting from a maritime to a continental climate. The city has an altitude of $791 \mathrm{~m}$ and develops along Stream Karaçomak, which is a tributary of Gökırmak (Öztürk and Özdemir, 2013). The first settlements in the city were positioned in the west of Karaçomak stream. However, dynamics, including organized industrial zone commencing operations (2009) and the establishment of the university (2007), led to the creation of new developmental zones in the north and south. The university campus is positioned in the north of the city and has a surface area of $2154685 \mathrm{~m}^{2}$ (215 ha) and a rural texture (Figure 1). While the area was outside of the neighboring area of the Municipality of Kastamonu until 2012, it was included in the borders of the municipality on 03/05/2012 due to becoming attractive, owing to the campus and the increasing construction. The preliminary design of the campus landscaping was completed in 2013. 


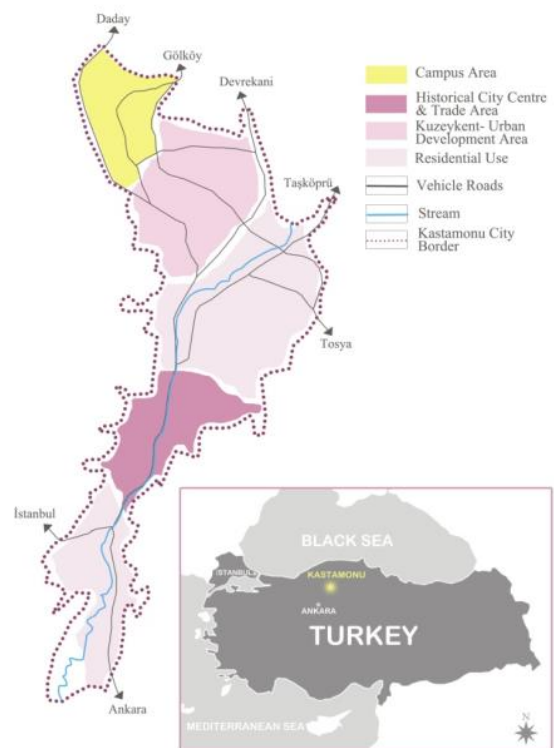

Figure 1. Kastamonu University's

Kuzeykent Campus geographical position

The field study was conducted in the first stage of the study. The plant samples collected during the field study, performed periodically from May to October, were pressed and dried according to herbarium rules. The dates of collection, numbers, habitats, localities, altitudes of the plant samples collected from the land and information about the plants were noted in the land. The plant samples were classified in the herbarium at a family and species level. Samples of each species were identified for comparison. The identification of the plant samples collected and dried was performed in the herbarium of Kastamonu University.

The work of 11 volumes named "Flora of Turkey and the East Aegean Islands" (Davis, 1965-1985; Davis et al., 1988; Güner et al., 2000) was used as the basic source for the identification of the plants. Forty-two taxons were identified as a result of the identification of the plants collected. The positions of the collected plants were marked using the ArcGIS 9.3 program and spatial projection was prepared. The gotten data were used in Figure 2.

\section{Findings}

Natural habitats are significant for urban macroform and life because they create healthy environments and decrease the negative effects of urban locations. University campus areas created by a natural and cultural system are significant parts of the urban ecosystem.

The preliminary design for the landscaping of the Kastamonu University campus area was completed in 2013. However, ideas of experts (ecologist, biologist, fauna expert and landscape architects) on natural landscape values of the area were not referred to in the survey stage of the project and no database was created. For this reason, the continuation of structural studies in the area damages the natural system. In this process, no effective planning and management can be conducted for the sustainability of the natural landscape values.

Construction fills $44.083 \mathrm{~m}^{2}$ of the area (approximately $215 \mathrm{ha}$ ) and $2.110 .602 \mathrm{~m}^{2}$ is a green outdoor area as of 2013. However, when the campus plan is completed, 136.345 $\mathrm{m}^{2}$ shall be a construction area and 2.018.340 $\mathrm{m}^{2}$ shall be a green outdoor area. There will be an increase of approximately $200 \%$ in the construction area. There is a green outdoor area with sufficient surface area. Since the northwest section of the area is an agricultural field, natural species are rare in this section. However, the fact is that: the south and southeast sections have more species diversity according to the north (Figure 2).

In Table 1, natural species revealing landscape value of the campus area are given. In the area, 42 taxons of 16 families were detected. Three of those taxons (Hyacinthella micrantha (Boiss.) Chouard, Euphorbia cardiophylla Boiss.\&Heldr., and Salvia hypargeia Fisch.\& Mey.) are endemic. According to IUCN, one of those taxons, Hyacinthella micrantha (Boiss.) Chouard, is included in the category of "likely to be in danger" (NT). The other two are included in the category of "least alarming" (LC). The species most frequently found in the area are Lepidium draba L. plants.

Certain species detected in the area were cultured and are used in the field of landscape architecture studies, particularly for the purpose of forming leaves, blossoms, fruit colors, focal points, and creating emphasis. Those herbaceous species, which live for one or several years, may be used together with other landscape elements. 


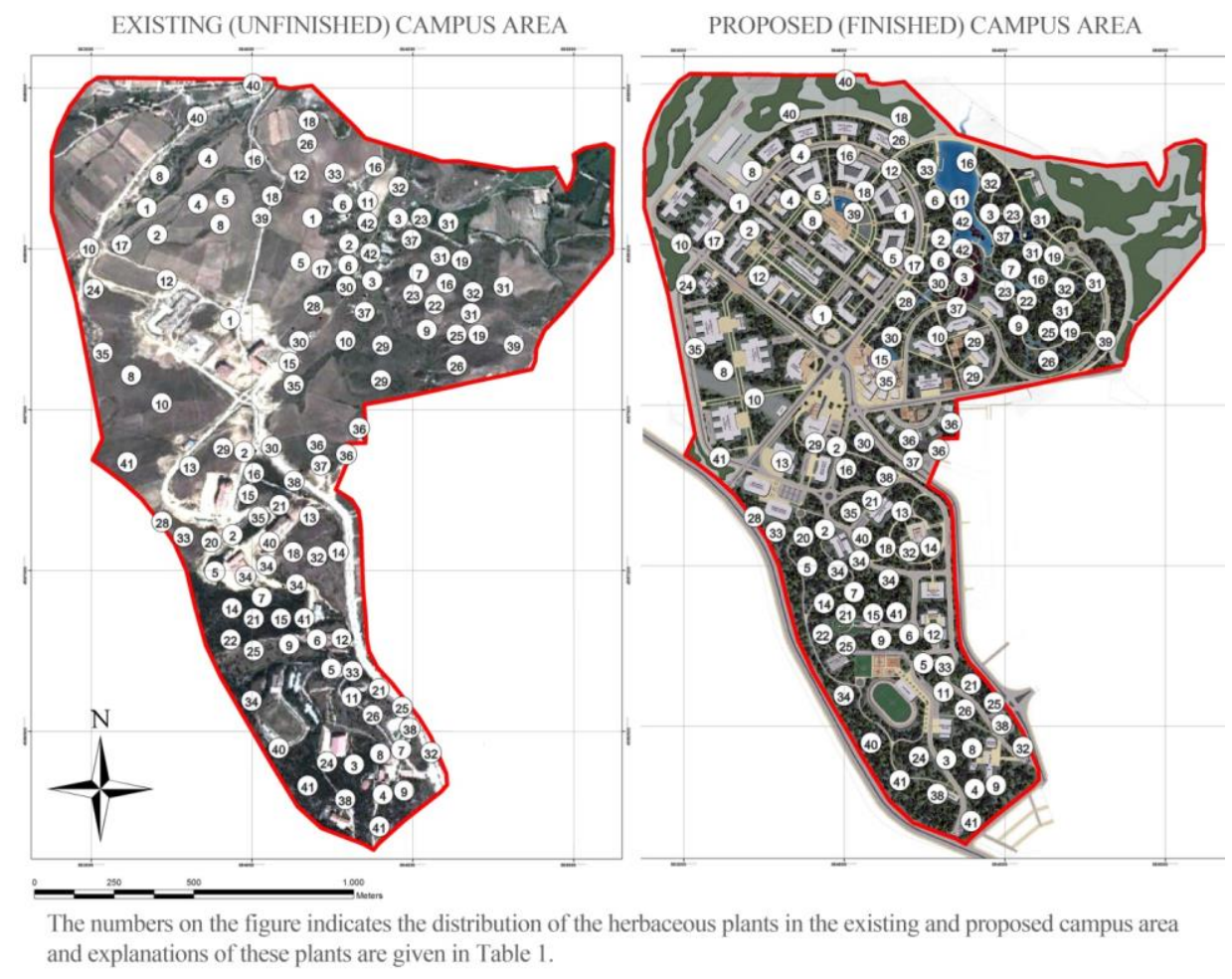

Figure 2. Spatial distribution of natural herbaceous species in Kastamonu University's Kuzeykent campus area

Adonis flammea Jacq., (red blossom color) Muscari armeniacum Leichtlin, Consolida orientalis (Gay.) Schröd., Salvia hypargeia Fisch.\& Mey, Globularia trichosantha Fisch.\& Mey., and Ajuga orientalis L., Viola sieheana Becker, Viola parvula Tineo detected in the area may be used as ground cover as the purplish and blue colors and may emphasize features. Berberis vulgaris L. is a species that should be evaluated with its yellow blossoms, red fruits, and aesthetic leaves. Furthermore, the species is a member of herbs. Further, labeling with of an educational nature is significant. Bellis perennis L., Muscari armeniacum Leichtlin, Viola sieheana Becker and Viola parvula Tineo are species that may be used around artificial lakes, which will be constructed in the campus area. Bellis perennis L., Tripleurospermum tenuifolium (Kit.) Freyn,
Senecio vernalis Waldst. and Kit., Erophila verna (L.) Chevall subsp. Verna are species with high visual value and are appealing when solitary, together, or in different areas with their white and yellow blossoms. Arabis nova Vill., Iberis taurica DC., Helianthemum canum (L.) Baumg., Silene vulgaris (Moench) Garcke var. commutata (Guss.) Coode \& Cullen, Genista albida Willd., and Tussilago farfara L. are species suitable for rock garden landscaping, which resemble natural living areas. Stelleria media (L.) vill. subsp. Media, Ajuga chamaepitys (L.) Schreber subsp. chia (Schreber) Arcangeli var. Chia, Ornithogalum oligoplyllum E.D. Clarke, Muscari armeniacum Leichtlin and Hyacinthella micrantha (Boiss.) Chouard may be used as ground cover with their visual features and may be used in landscaping when cultured 
Table 1. Herbaceous species detected on the Kastamonu University campus

\begin{tabular}{|c|c|c|c|c|}
\hline No & Family & Species & Blossom color & Blooming time \\
\hline 1 & Ranunculaceae & Consolida orientalis (Gay.) Schröd. & Purple-lilac & May-August \\
\hline 2 & & Adonis flammea Jacq. & Red & April-June \\
\hline 3 & Berberidaeceae & Berberis vulgaris $\mathrm{L}$. & Yellow & May \\
\hline 4 & Papaveraceae & Fumaria officinalis L. & pink & May \\
\hline 5 & Brassicaceae & Capsella bursa-postoris (L.) Medik. & White & $\begin{array}{l}\text { December- } \\
\text { January }\end{array}$ \\
\hline 6 & & Arabis nova Vill. & White & May \\
\hline 7 & & Arabis sagittata (Bertol.) DC. & White & April \\
\hline 8 & & Lepidium draba $\mathrm{L}$. & $\begin{array}{l}\text { White or } \\
\text { yellow }\end{array}$ & April - May \\
\hline 9 & & Iberis taurica DC. & $\begin{array}{l}\text { From white to } \\
\text { lilac }\end{array}$ & April -June \\
\hline 10 & & $\begin{array}{l}\text { Erophila verna }(\mathrm{L} .) \text { Chevall subsp. } \\
\text { verna }\end{array}$ & White & March-June \\
\hline 11 & Resedaceae & Reseda lutea $\mathrm{L}$. var. lutea & Yellow & April-August \\
\hline 12 & Cistaceae & Helianthemum canum (L.) Baumg. & Yellow & April -July \\
\hline 13 & Violaceae & Viola sieheana Becker & $\begin{array}{l}\text { From white to } \\
\text { bluish white }\end{array}$ & March-June \\
\hline 14 & & Viola parvula Tineo & Creamy white & April-July \\
\hline 15 & Caryophylaceae & $\begin{array}{l}\text { Stelleria media (L.) Vill. subsp. } \\
\text { media }\end{array}$ & White & April -June \\
\hline 16 & & $\begin{array}{l}\text { Hollosteum umbellatum L. var. } \\
\text { glutinosum (Bieb.) Gay }\end{array}$ & White & \\
\hline 17 & & $\begin{array}{l}\text { Silene dichotoma Ehrh. subsp. } \\
\text { sibthorpiana (Reichb.) Rech. }\end{array}$ & White or pink & May-July \\
\hline 18 & & $\begin{array}{c}\text { Silene vulgaris (Moench) Garcke } \\
\text { var. commutata (Guss.) Coode \& Cullen }\end{array}$ & White & May-August \\
\hline 19 & Fabaceae & Genista albida Willd. & From white to & May-June \\
\hline 20 & Rosaceae & Potentilla recta $\mathrm{L}$. & From white to & July \\
\hline 21 & & Cydonia oblonga Miller & White & May-June \\
\hline 22 & & Rosa canina $\mathrm{L}$. & Pink-red & May-July \\
\hline 23 & & $\begin{array}{l}\text { Cotoneaster nummularia Fisch. \& } \\
\text { Mey }\end{array}$ & White & April-June \\
\hline 24 & Astaraceae & $\begin{array}{l}\text { Tripleurospermum tenuifolium } \\
\text { (Kit.) Freyn }\end{array}$ & White & May-June \\
\hline 25 & & Senecio vernalis Waldst. \& Kit. & Yellow & March-August \\
\hline 26 & & Tussilago farfara $\mathrm{L}$. & Yellow & March- April \\
\hline 27 & & $\begin{array}{l}\text { Trogopogon longirostris Bisch. ex } \\
\text { Schultz Bip. }\end{array}$ & Purple & April -July \\
\hline 28 & & Trogopogon aureus Boiss. & Yellow & $\begin{array}{c}\text { June- } \\
\text { September }\end{array}$ \\
\hline 29 & & $\begin{array}{l}\text { Pilosella pilpselloides (Vill.) Sojak } \\
\text { subsp. piloselloides }\end{array}$ & Yellow & June-August \\
\hline 30 & & Bellis perennis $\mathrm{L}$. & White-Pink & March-August \\
\hline 31 & Globulariaceae & $\begin{array}{l}\text { Globularia trichosantha Fisch.\& } \\
\text { Mey. }\end{array}$ & Purple & April -July \\
\hline 32 & Lamiaceae & Ajuga orientalis $\mathrm{L}$. & Purplish & April -July \\
\hline 33 & & $\begin{array}{l}\text { Ajuga chamaepitys (L.) Schreber } \\
\text { subsp. chia (Schreber) Arcangeli var. } \\
\text { chia }\end{array}$ & Yellow & April -July \\
\hline 34 & & Lamium amplexicaule $\mathrm{L}$. & Purplish & $\begin{array}{l}\text { February- } \\
\text { November }\end{array}$ \\
\hline 35 & & Salvia viridis $\mathrm{L}$. & $\begin{array}{l}\text { Lilac-purple or } \\
\text { white }\end{array}$ & March-July \\
\hline 36 & & Salvia hypargeia Fisch.\& C.A.Mey & Purplish -blue & June-July \\
\hline 37 & & Stachys аппиа (L.) L. var. аппиа & Creamy yellow & $\begin{array}{c}\text { March- } \\
\text { September }\end{array}$ \\
\hline 38 & Euphorbiaceae & $\begin{array}{l}\text { Euphorbia cardiophylla Boiss. \& } \\
\text { Heldr. }\end{array}$ & Yellow & March-June \\
\hline 39 & Rubiaceae & $\begin{array}{l}\text { Cruciata taurica (Pallas ex Willd.) } \\
\text { Ehrend }\end{array}$ & Pink-Purple & March- April \\
\hline 40 & Liliaceae & $\begin{array}{l}\text { Ornithogalum oligoplyllum E.D. } \\
\text { Clarke }\end{array}$ & White & April -July \\
\hline 41 & & Muscari armeniacum Leichtlin & Bright blue & March-May \\
\hline 42 & & $\begin{array}{l}\text { Hyacinthella micrantha (Boiss.) } \\
\text { Chouard }\end{array}$ & Bright blue & March-May \\
\hline
\end{tabular}




\section{Results and Suggestions}

Today, green areas are rapidly diminishing, particularly in metropolitan cities, agricultural and even natural areas where their function changes rapidly or disappears altogether in the name of development activities. Development models that ignore source value lead to the loss of natural areas, disintegration of outdoor and green areas, pollution of water sources and an overall decrease in the harmony of nature. At this point, landscape planning aims for a systematic solution to the problem arising between the natural environment and the constructed environment (Cadenasso and Pickett, 2008).

When the population changes (for 19602013) in the city of Kastamonu, which is an example of a medium sized city which was assessed, it is observed that while urban population increases, the rural population decreases (http://www.tüik.gov.tr, 2013). Fast urbanization and arising urban land rent depend on this. Immovable properties are speculation tools within economic structure. A shortage of protection awareness and economic weaknesses make it difficult to protect natural landscape values.

Due to fast changing urban dynamics and requirements in the city of Kastamonu, the district of Kuzeykent and its neighborhood has become a significant rent region where construction is increasing. Existing planning and management practices fail to solve the problems arising from irregular and fast construction. This increases the requirement for green infrastructure works, which are on a multi-focus-scale and are based on the collaboration of relevant instates-institutions. In the planning works performed for Kastamonu with various contents, communication or integration of this region within the city center and other sub-regions should be provided through green corridors.

The Kastamonu University campus is positioned in the district of Kuzeykent, which is vitally significant, not only in itself but also for the entire city. The campus area is one of the significant prestigious areas within the city. Landscaping planting works in the area have not been started. Construction work in the area has been completed at a proportion of $30 \%$. The fact that work has not been performed in $70 \%$ of the remaining area makes it possible to protect the species detected and evaluate them in landscaping. The fact that the campus area landscaping plan is at the beginning stage increases the significance of the study. The identified species were digitally processed to Campus Landscaping Avan project via ArcGIS 9.3

At this scope the study is significant for providing sustainability of natural landscape areas. Suggestions for the campus area in the light of the data acquired are given as follows:

$\checkmark \quad$ Protecting the campus landscaping project primarily will strengthen the predicted values and it should have a holistic fiction property to be integrated with existing and future projects.

The campus landscaping project should create a good city campus which is well associated with the environment at the upper scale. At the subscale it should use and develop the own potential.

$\checkmark \quad$ The newly planned university campus should strengthen the forest texture image of the city which covers the environment of the city and accept it. Also it should brought to the fore the native herbaceous species.

$\checkmark$ Universities should be designed as education areas as they are higher education institutions. In this manner, many occupational groups in elementary and secondary education institutions as well as university students shall have the chance to know flora and fauna members in their living spaces. Again, labeling the species to be used in the squares, avenues and other areas to be created on the campus (particularly the endemic ones) is important. Giving the names, (Latin and Turkish), families, motherlands and some other (mythological, medical, and economic) features of plants is necessary for educational terms.

Furthermore, increasing the plant knowledge of persons who study, lecture, and work in various scientific branches should be considered as a fact that would bring environmental sensitivity. 
$\checkmark \quad$ A large part of the budget should be allocated for landscaping in the campus area, resulting in a wide-open green outdoor area for plants. Using the plants detected in Table 1, which are suitable for landscaping with blossom color and other features, are more economical than using exotic plants that are outsourced.

$\checkmark$ Planting works to be performed in the entire area should be handled in the manner that they will support and protect natural areas and therefore provide sustainability. The fact that the usage intensity of natural species is high will decrease the water consumption and maintenance operations. Johnson and Castleden (2011) suggested that increasing the use of natural species decreases water consumption (Sögüt et al., 2013).

$\checkmark$ It shall be suitable to select noninvader species from foreign countries, which may support (including nutrition, accommodation) any natural species existing in natural or nature-identical areas (including birds, reptiles). For instance, it is recommended that cultured types of species be used, including blackberries, dog roses, and mulberries for the nutrition of birds existing in wild life. These studies supporting natural life shall enable users to have knowledge about natural life.

$\checkmark$ All environmental studies conducted/to be conducted in the campus area, particularly in the south and southwest sections, should be approached more carefully. The species detected in the area before the beginning of the study, particularly endemic or endangered plants (Hyacinthella micrantha (Boiss.) Chouard, Euphorbia cardiophylla Boiss.\&Heldr. and Salvia hypargeia Fisch.\& C.A.Mey) should firstly be protected in the area (in-situ) or in a different area (ex-situ) and later they should be reproduced by being cultured. These species should be evaluated in the design or planning works with certain aesthetic and functional qualities.

$\checkmark \quad$ Since the north and northeast regions are university development areas and are generally agricultural fields, plans suitable for the convenient use and various research and trial fields or recreational uses should be preferred.
It is considered that educational, didactic, and aesthetic plant design dealing with different themes in different areas of the campus area shall contribute to the vision of the university as well.

Besides the university campus areas are educational institutions they should also show the city image with their physical structure. Thus; the universities are being the educational and cultural investments of the region and city in terms of social, cultural and economic development where they were founded. Because of these; it has importance that it should have design principles which are holistic, ecological and care the sustainable environmental values which is also open to development and growth.

As a result, it is necessary to design the relationship between natural and constructed areas for habitable urban environments. At that point, it is necessary that the planting and maintenance works within a plan-project made for the campus area are institutionalized and maintained by professionals. It will be possible to provide sustainability through planting works to support and protect natural areas but only in this manner. In this case, the most significant means of sustainability of natural landscape values becomes the sensitivity to the environment of the management and decision makers themselves.

\section{References}

Aba Al-Khail, Gawas; Abdel Rahman AlMuhanna, Mohi-Din Mahmud, 2005. Ecosystems and humans. Saudi Arabia (in Arabic).

Altay V., 2012. Decorative plants of Mustafa Kemal University Tayfur Ata Sökmen Campus (Hatay), The Black Sea Journal of Sciences 3: 2 (6), P. 11-26.

Andersson E., 2006. Urban landscapes and sustainable cities. Ecology and Society 11(1) 34.

Arslan M., Perçin H., Barıș E., Uslu, A., 1996. A research on certain evergreen plant species fitting the climatic conditions of Central Anatolia Region. Ankara University, Publications of Faculty of Agriculture, No: 1470, Ankara.

Akman Y., 1990. Climate and bio-climate (Bio-climate methods and turkey climates). Palme Publication and Distribution, Ankara-Turkey.

Aslanboğa İ., 2002. Principles of planting in woody plants. Aegean Forestry Research Directorate, Izmir.

Baizakov S., Tilenov A. 2013. Problems and prospects of development of forest using in 
Kazakhsta., Bulgarian Journal of Agricultural Science, 19 (No 4) 2013, 875-884

Berkes F., Colding J., Folke C. 2003. Navigating social-ecological systems. Building Resilience for Complexity and Change, Cambridge University Press, Cambridge, UK., 24.

Braun S., Fluckiger W. 1998. Soil amendments for plantings of urban trees. Soil and Tillage Research, 49 (3): 201-209.

Breheny M. J. 1992 Sustainable development and urban form. Pion Limited European Research in Regional Science, No.2, ISBN 085086 160, 292 pp. London,

Cadenasso M. L., Pickett S.T.A. 2008. Urban principles for ecological landscape design and maintenance: Scientific fundamentals, Cities and the Environment, 1 (2):4, 16 pp.

Cinar H.S., Erdoğan R., Altıncekic H., Oktay, E. 2013. Sustainability of the Mediterranean landscape in the urban: The case study of AntalyaKonyaaltı region, Journal of Food, Agriculture \& Environment 11 (1): 738 - 744

Çetinkaya G.. 2013. New approaches in urban landscape planning: Green infrastructure and green corridors, $5^{\text {th }}$ Congress of Landscape Architecture / 14-17 November 2013 - Adana 265277.

Davis P. H. 1965-1985. Flora of Turkey and the East Aegean Islands Vol.: 1-9, Edinburgh University Press., Edinburgh.

Davis P. H., Mill R. R., Tan K. 1988. Flora of Turkey and the East Aegean Islands. Volume 10. Edinburgh University Press, Edinburgh.

Frey H. 1999. Designing the City: Towards a more sustainable urban form (Spon, London).

Güner A., Özhatay N., Ekim T., Baser K. H. C., 2000. Flora of Turkey and the East Aegean Islands. Volume 11. Edinburgh University Press, Edinburgh.

Johnson L.; Castleden H. 2011. Greening the campus without grass: using visual methods to understand and integrate student perspectives in campus landscape development and water sustainability planning. Area, 43 (3): 353-361.

Haughton G., 1997. Developing sustainable urban development models, cities, The International Journal of Urban Policy and Planning, Volume 14, Issue 4, Pages 189-195.

Leszczynski N. A. 1999. Planting the landscape. John Wiley and Sons, Inc, p: 208. London.

McPherson E. G. 1992. Accounting for benefits and costs of urban greenspace. Landscape and Urban Planning 28:41-51.

Moore R. C., 2002. Plants for play. ISBN: 9780944661185, Mig Communications, California.

Olsson P., Folke C., Hahn T. 2004. Socialecological transformation for ecosystem management: the development of adaptive comanagement of a wetland landscape in Southern Sweden. Ecology and Society 9 (4):2.

Özinan C. 1977. The effect of problems caused by fast growth in cities on housing and spatial life, Gaziantep model, Gazi University Unpublished Master Thesis, Ankara-Turkey.

Öztürk S., Özdemir Z. 2013. The effect of urban outdoor and green areas on life quality "Kastamonu model", Kastamonu University, Journal of Faculty of Forestry, 2013, 13 (1): 109116.

Shayaa Al-Shayaa, M., El Tayeb Muneer, S., Elriwaisi N. A. 2012. Assessing the level of environmental awareness of the workers on environment in the industrial cities of Riyadh, Kingdom of Saudi Arabia, Bulgarian Journal of Agricultural Science, 18 (No 2) 2012, 254-262

Söğüt Z., Bozgoğan E., Şenol D. 2013, Campus planting, Landscape Architecture $5^{\text {th }}$ Congress, Adana 853-866.

Tyruainen L. 1997. The amenity value of the urban forest an application of the hedonic pricing method. Landscape and Urban Planning, 37: 211222.

TÜİK 2013. Kastamonu address based city center population data, Kastamonu-Turkey.

Ürgenç S., 1990. General plantation and forestation technique. Istanbul University Publications, No: 3644, Istanbul.

Y1lmaz K.T., 1997. Ecological diversity of the Eastern Mediterranean region of Turkey and its conservation, Biodiversity and Conservation, 7 : (1), p. 87-96 